\title{
Ultrasonic spray deposition of SiC nanoparticles for laminate metal composite fabrication
}

\author{
1 Mina Bastwros ${ }^{1}$, Gap-Yong Kim* \\ 2 Department of Mechanical Engineering, Iowa State University, Ames, IA 50011, USA \\ $5 *$ Corresponding author \\ 6 Department of Mechanical Engineering, Iowa State University, 2034 H.M. Black Engineering \\ 7 Building, Ames, IA 50011, USA. \\ $8 \quad$ Tel.: +1 5152946938 \\ $9 \quad$ Fax: +1 5152943261 \\ 10 E-mail: gykim@,iastate.edu \\ 11 \\ $12 \quad{ }^{1}$ E-mail: $\underline{\text { minamhb@,iastate.edu }}$ \\ 13
}

\section{1. Abstract}

15 2. Nanoparticles have been increasingly used in functional and composite materials. One of 16 the challenges, however, has been dispersing and controlling the nanoparticle clusters. In

17 this study, the deposition of $\mathrm{SiC}$ nanoparticles via ultrasonic spraying process was

18 investigated for a potential application in synthesis of laminate metal composites. The

19 governing parameters of the ultrasonic spraying process which includes suspension and

20 spraying parameters, and their influence on the deposited structure have been investigated.

21 These parameters determine the driving force that transports the atomized droplets to the

*Corresponding author. Tel. (+1) 515-294-6938

E-mail address: gykim@iastate.edu 
1 substrate, the amount of liquid phase present on the substrate, and its evaporation rate. By

2 controlling these parameters, deposition structures ranging from a few $\mathrm{SiC}$ nanoparticles to

3 cluster sizes of $10 \mu \mathrm{m}$ could be obtained. The potential of using ultrasonic spraying to

4 fabricate laminate composites reinforced at the interfaces with nanoparticles was

5 investigated. Composites with a uniform deposition of $\mathrm{SiC}$ at the interface showed better

6 mechanical properties than those with a nonuniform deposition when compared at the same

$7 \quad$ SiC loading.

83.

9 4. Keywords: ultrasonic spraying; nanoparticle; composite; deposition

$10 \quad 5$.

116.

12 


\section{Introduction}

Various techniques have been used in material coating or surface deposition, including

3 tape casting [1], thermal spraying [2], plasma spraying [3], electrostatic spray deposition [4],

4 spray deposition [5], spray pyrolysis [6], and ultrasonic spray deposition [7]. Among these

5 techniques, ultrasonic spraying offers several unique and desirable characteristics. The

6 ultrasonic spraying nozzle vibrates at high frequency using two piezoelectric discs and an

7 amplifier. This makes the liquid leave the nozzle tip in the form of mist that has a narrow

8 droplet size distribution and a very low spraying velocity (in the order of $1 \mathrm{~m} / \mathrm{s}$ ) compared with

9 other spraying techniques [8]. It is a process that is favored by its simplicity and low cost, in

10 addition to its flexibility in producing thin multilayered deposited structures [9]. It offers a

11 relatively moderate deposition surface temperatures of $100-500^{\circ} \mathrm{C}[10]$. Accordingly, a wide

12 variety of substrate materials can be used [11] by tuning the spraying parameters. The

13 technique also allows accurate control of the deposition rate [12] and deposition structure [7].

14 In a recent study, the deposition structures of ultrasonic and handheld spraying techniques were

15 compared, and the ultrasonic spraying technique resulted in a smoother and more uniform

16 deposition structure [13]. It has been used to fabricate fuel cell electrodes [14], thin films [15,

17 16], nanocatalysts [17], high temperature oxidation resistant coatings [16], and electrochromic

18 windows [18]. The atomized droplet size, which significantly influences the deposition structure

19 and the spray quality, is mainly determined by the liquid properties (surface tension and density)

20 and the nozzle vibration frequency [19]. Moreover, spraying parameters, such as the nozzle

21 vibration frequency, flow rate, deposition surface temperature [20], spraying air pressure [21],

22 and spraying distance [12], affect the final deposition structure.

*Corresponding author. Tel. (+1) 515-294-6938

E-mail address: gykim@iastate.edu 
In this study, the ultrasonic spraying is used for spraying nano-suspension systems to

2 deposit nanoparticles on substrate materials. Nano-suspensions or nano-fluids are liquid with

3 homogeneously suspended nano-sized particles [22], which may be metals [23], oxides [24],

4 carbides [16], and carbon structured materials [25]. One of the main advantages of using

5 nanoparticle suspensions is the low tendency for particle agglomeration and sedimentation,

6 which will keep the particles suspended and dispersed throughout the operation and may

7 potentially improve the quality of deposited layer [22]. Nano-suspension spraying has been

8 used in many applications. It has been used to process granular nanoparticles using various

9 spraying techniques, where the suspension is sprayed and the droplet dries while traveling and

10 can then be collected [26-29]. During drying, the nanoparticles can be self-assembled in various

11 morphologies depending on the process conditions [30]. Moreover, spraying suspension of

12 CNT has been used to deposit a CNT network film on a substrate to fabricate a conductive film

13 for electronic applications [31, 32]. Hand spraying of CNT micro-ball suspension was used to

14 fabricate dye-sensitized solar cells [33]. Spraying of nano-suspension was also used to fabricate

15 solid oxide fuel cells using a conventional spraying atomizer [34]. In a recent study, ultrasonic

16 spraying was used to deposit graphene flakes films on polymer-coated glass. The researchers

17 chose the ultrasonic spraying technique as it produced relatively small droplets of a few

18 micrometers that allowed rapid solvent evaporation [35].

19 In this study, the ultrasonic spraying technique was applied to accurately control the

20 deposition structure of nanoparticles needed to produce layered metal composites reinforced by

21 nanoparticles at the interfaces. Previous studies demonstrated that laminated composites can be

22 designed to improve several characteristics, including damage tolerance [36], impact toughness

*Corresponding author. Tel. (+1) 515-294-6938

E-mail address: gykim@iastate.edu 
1 [37], fatigue behavior [38], corrosion resistance, wear resistance, formability, and ductility [39].

2 In manufacturing of metal laminate composites reinforced with nanoparticles, several studies

3 were found, each of which employed techniques involving manual spreading of the

4 reinforcements [40], immersing the substrate in suspension systems [41], and air gun spraying to

5 deposit nanoparticles [42]. The challenge, however, has been in trying to precisely control the

6 spatial distribution of the reinforcement elements.

7 In this study, the deposition of silicon carbide $(\mathrm{SiC})$ nanoparticles using ultrasonic

8 spraying method was investigated for the purpose of synthesizing a multilayer composite made

9 of AZ31 magnesium alloy. The study entailed understanding the effects of suspension and

10 spraying parameters on the deposited microstructure. The size and amount of nanoparticles in

11 the ethanol suspension affect the initial atomization droplet size, which was calculated using a

12 theoretical model. The effects of the spraying parameters (flow rate, substrate surface

13 temperature, air pressure, and nozzle to substrate distance) on the deposition morphology were

14 investigated to identify appropriate parameter ranges to make the multilayer composite. Finally,

15 an AZ31 magnesium alloy laminate composite reinforced by silicon carbide ( $\mathrm{SiC}$ ) nanoparticles

16 was fabricated, and the potential use of ultrasonic spraying technique for laminate composite

17 synthesis was discussed.

\section{8. Experimental procedure}

19 Ultrasonic spraying is a promising technique that can coat surfaces with various

20 nanoparticles and chemicals, and in so doing, precisely control the deposited microstructure. In

21 this study, an ultrasonic deposition system (Exacta-Coat Ultrasonic Coating System, Sono-Tek

22 Corp.) as shown in Fig. 1 was used to perform the spraying. The system features a sonic syringe

*Corresponding author. Tel. (+1) 515-294-6938

E-mail address: gykim@iastate.edu 
1 that controls the flow rate of the suspension and provides bursts of vibration to prevent the

2 suspended particles from developing sedimentation and agglomeration.

3 The spray-deposited structure can be influenced by various processing parameters, which

4 may be classified into two categories: suspension and spraying parameters. The suspension

5 parameters are the suspended particle type, size, and $\mathrm{SiC}$ concentration. Suspension

6 concentrations of $0-16$ wt.\% of $\mathrm{SiC}$ were used to study the effect on the surface tension for two

7 different particle sizes, 80 and $800 \mathrm{~nm}$. For the $800 \mathrm{~nm} \mathrm{SiC}$, it was challenging to keep the

8 suspension homogeneous during the spraying process due to the particles developing

9 sedimentation and tendency to clog the spraying tubes and system. On the other hand, the 80

$10 \mathrm{~nm} \mathrm{SiC} \mathrm{particle} \mathrm{suspension} \mathrm{could} \mathrm{be} \mathrm{kept} \mathrm{stable} \mathrm{for} \mathrm{days,} \mathrm{which} \mathrm{made} \mathrm{it} \mathrm{favorable} \mathrm{for} \mathrm{the}$

11 spraying process. Nanoparticles were mixed into ethanol and sonicated for six hours in an

12 ultrasonic bath to achieve a stable and homogenous suspension [43]. The surface tension was

13 measured using the pendant drop method [44]. The important spraying parameters that could

14 affect the deposition structure are the deposition surface temperature $(\mathrm{T})$, the spraying suspension

15 flow rate $(\mathrm{Q})$, the spraying air pressure $(\mathrm{P})$, and the nozzle distance (D) [8]. Each parameter was

16 investigated by analyzing the deposited structure qualitatively under a scanning electron

17 microscope (SEM). For spraying, a low suspension concentration was prepared using the $80 \mathrm{~nm}$

$18 \mathrm{SiC}$ particles with a concentration of $0.1 \mathrm{wt} . \% \mathrm{SiC}$.

19 Fig. 2 shows a schematic overview of the spraying process and the spraying path. A

20 total of 12 passes were used for each sample with a nozzle velocity of $10 \mathrm{~mm} / \mathrm{sec}$. The spacing

21 between the centers of two adjacent lines was $2 \mathrm{~mm}$, which provided small enough spacing so

*Corresponding author. Tel. (+1) 515-294-6938

E-mail address: gykim@iastate.edu 
1 that the spray area overlapped and the final deposited structure was uniform. The detailed

2 spraying conditions and parameters are summarized in Table 1.

A laminate composite of magnesium alloy (AZ31) sheets and SiC nanoparticles were

4 fabricated. The AZ31-SiC laminate composite was comprised of 15 layers of AZ31 sheets (80-

$5100 \mu \mathrm{m}$ thick) sprayed with $\mathrm{SiC}$ at the interface. The chemical composition of the AZ31 sheet

6 is provided in Table 2. Composites with different $\mathrm{SiC}$ loadings of $0,0.15,0.3$, and 0.6 wt.\%

7 were synthesized.

8 The experimental setup used for composite synthesis is shown in Fig. 3. The die was

9 made of H13 tool steel and was lubricated by spraying a thin layer of boron nitride to prevent

10 potential reaction between the sample and the die at elevated temperatures. The consolidation

11 was performed in two stages. First, a pe-compaction pressure of $50 \mathrm{MPa}$ was applied to the

12 stacked layers at room temperature. Then the temperature was raised to the mushy zone of the

13 AZ31 alloy (between the solidus and liquidus temperature) [45] while $50 \mathrm{MPa}$ of pressure was

14 maintained. The stacked layers were hot pressed under $50 \mathrm{MPa}$ for 20 minutes at $610^{\circ} \mathrm{C}$, at

15 which temperature the liquid phase is about $9 \%$. The obtained composites were cut using a

16 diamond saw and were polished to the final dimensions $(0.9 \mathrm{~mm}$ in thickness and $1.2 \mathrm{~mm}$ in

17 width) needed to perform the three-point bend test. The flexural stress and flexural strain were

18 recorded using the materials testing system.

\section{9. Results and discussion}

20 The droplet size is one of the main parameters that affects the deposited microstructure

21 and is mainly determined by the ultrasonic frequency of the nozzle and the suspension properties

22 (surface tension and density) [19]. The droplet size can be approximately estimated by Eqn. (1)

*Corresponding author. Tel. (+1) 515-294-6938

E-mail address: gykim@iastate.edu 
1 [8], which represents a model that predicts the diameter of the atomized droplet exiting from the

2 ultrasonic nozzle used in various studies [7, 8, 46]:

$$
d_{d}=2 \frac{\sqrt[3]{2}}{\pi}\left(\frac{\pi \sigma}{\rho f^{2}}\right)^{\frac{1}{3}}
$$

3 where, $\sigma$ and $\rho$ are the surface tension and the density of the suspension, respectively; and $f$ is the

4 ultrasonic nozzle frequency. Note that the surface tension and density have opposite effect on

5 the atomized droplet size.

6 Fig. 4(a) shows the relation between surface tension and particle loading for two different

$7 \quad \mathrm{SiC}$ particle sizes $(80 \mathrm{~nm}$ and $800 \mathrm{~nm})$. The surface tension increased as the $\mathrm{SiC}$ loading

8 increased. Zhu et al. [47] reported a similar observation. Since the particles tend to

9 agglomerate at the gas-liquid interface, it increases the concentration of particles at the surface.

10 At the gas-liquid interface, two forces, repulsive force (electrostatic) and attractive force (van der

11 Waals), compete with each other [48] and can affect the surface free energy of the suspension.

12 At a low concentration, the particles are farther away from each other, and therefore, the particle

13 interaction is lower, resulting in a lower surface tension according to Saeid et al. [49]. On he

14 other hand, as the concentration increases, the distance between the particles becomes shorter,

15 which increases the attractive force and results in surface free energy increase [49]. The

16 observation also agrees with findings from other researchers [50].

17 It was observed that the suspension properties were significantly affected not only by the

18 amount of the suspended particles but also by their size. When the same amount is loaded, the

19 smaller particle size increases the total free surface area, which results in increase of the total

20 surface free energy [48]. Moreover, the surface tension of the suspension affects the deposited

*Corresponding author. Tel. (+1) 515-294-6938

E-mail address: gykim@iastate.edu 
1 structure. The morphology of the deposited structure becomes more uniform at a lower surface

2 tension due to enhanced wetting that helps to enlarge the droplet spread area upon contacting the 3 surface and allows merging of these droplets [51].

$4 \quad$ Using Eqn. (1), the droplet sizes for various conditions were calculated as shown in Fig.

5 5. It can be noticed that the change in droplet size is reversed depending on the size of the

6 suspended particle. As mentioned earlier, the surface tension and density have the opposite

7 effect on atomization droplet size as the particle loading is increased. Since the change in

8 surface tension is much lower for larger particles as the loading is increased, the droplet size

9 decreased for larger particles with increasing loading (see Fig. 5(a)). However, for the typical

10 range of suspension concentration used in spraying, atomization droplet size is largely

11 determined by the nozzle frequency as shown in Fig. 5(b). Since the spray system has a fixed 12 nozzle frequency of $120 \mathrm{kHz}$, the expected droplet size is in the order of $15 \mu \mathrm{m}$.

13 The final deposited droplet size may vary depending on the evaporation and drying

14 dynamics of the droplet when it contacts the heated surface [52]. Because the prediction of the

15 final droplet size before colliding into the substrate is complex, the deposition patterns of single

16 droplets were experimentally measured. A single pass spray was applied on the heated

17 substrate with a fast spraying speed of $100 \mathrm{~mm} / \mathrm{sec}$. The spraying was performed using a 0.1

18 wt. $\% \mathrm{SiC}(80 \mathrm{~nm})$-ethanol suspension at $300^{\circ} \mathrm{C}$, under air pressure of $0.5 \mathrm{kPa}$, and with a

19 suspension flow rate of $0.25 \mathrm{ml} / \mathrm{min}$. SEM images of the single droplets are shown in Fig. 6.

20 It can be observed that nanoparticles form coffee ring patterns upon deposition and tend

21 to cluster at the gas-liquid interface of the droplet [53]. Ring-like stains are commonly seen in

22 the drops containing dispersed solutes. When the particles are homogeneously dispersed in the

*Corresponding author. Tel. (+1) 515-294-6938

E-mail address: gykim@iastate.edu 
1 suspension droplet, the droplet spreads and the suspension begins to evaporate as soon as it

2 collides with the surface. At the gas-liquid contact line, the suspended particles begin to deposit

3 and cause the pinning of the contact line. Upon further evaporation, the droplet shrinkage is

4 hindered in the horizontal direction, but it is allowed in the vertical one. The pinning of the

5 contact line causes the migration of the liquid to the contact line to replenish the evaporated

6 liquid. As a result, the particles carried by the liquid deposit and cluster at the contact line [54].

7 The size of the deposited droplet patterns varies in a wide range with a minimum of few microns

8 to a maximum of about $50 \mu \mathrm{m}$. Most of the patterns, however, ranged between 20 and $50 \mu \mathrm{m}$,

9 which are larger than the initially estimated atomized droplet size of $15 \mu \mathrm{m}$, since the droplets

10 spread due to the momentum as soon as it contacts the surface.

11 The effect of the flow rate on the deposited structure is shown in Fig. 7. The samples

12 were sprayed using a $0.1 \mathrm{wt} . \% \mathrm{SiC}(80 \mathrm{~nm})$-ethanol suspension at the heat plate temperature of

$13350^{\circ} \mathrm{C}$, under the air pressure of $0.5 \mathrm{kPa}$, and at the flow rates of $0.25-1.00 \mathrm{ml} / \mathrm{min}$. As the

14 flow rate increased, the SiC cluster size increased. Fig. 7(d) and (f) show that the SiC particles

15 form a continuous line of segregated particles, which is interrupted by large clusters of $\mathrm{SiC}$

16 nanoparticles. The formation of such clusters during evaporation depends on the evaporation

17 time of the suspension during its transportation to the substrate and after deposition. As the

18 flow rate increases, the amount of liquid phase transported during spraying is higher, resulting in

19 a longer evaporation time. The presence of a relatively large amount of the liquid phase on the

20 deposition substrate allows the suspended particles to segregate and cluster at the contact lines.

21 In contrast, spraying at a lower flow rate will help improve the uniformity and homogeneity of

22 the deposited microstructure. The deposited structure will be favored with relatively smaller

*Corresponding author. Tel. (+1) 515-294-6938

E-mail address: gykim@iastate.edu 
1 discontinuous nanoparticle clusters with a narrower clusters size distribution (Fig. 7(a)). For the

$20.25 \mathrm{ml} / \mathrm{min}$ sample, the deposited nanoparticle cluster size varied from a single particle $(80 \mathrm{~nm})$

3 up to $20 \mu \mathrm{m}$. For the $1.00 \mathrm{ml} / \mathrm{min}$ sample, small clusters were observed in the range of few

4 particles up to $70 \mu \mathrm{m}$. Naoki et al. [55] reported similar results where they studied the effect of

5 the spraying time on the uniformity of the deposited structure. They reported that the shorter the

6 spraying time (a smaller spraying amount) resulted in an evenly coated surface with a uniform

7 structure while the longer one resulted in a non-uniform, highly textured deposited layer [55].

8 As the flow rate increases, the deposited structure becomes more porous. In a typical

9 spraying environment, the deposited structure is formed by the accumulation of the sprayed

10 particles of each spraying pass. The morphology and texture of the dried deposited layer affect

11 the drying dynamics of the successive sprayed layer [56]. When the dried deposited layer

12 surface is rough (with high peaks and low valleys), the freshly deposited droplets dry on the

13 peaks and do not fill the cavities on the surface due to the surface tension forming porous

14 structures [55].

15 The effect of the deposition surface temperature is shown in Fig. 8. The spraying was

16 performed using a $0.1 \mathrm{wt} . \% \mathrm{SiC}(80 \mathrm{~nm})$-ethanol suspension under an air pressure of $0.5 \mathrm{kPa}$,

17 and with a suspension flow rate of $0.25 \mathrm{ml} / \mathrm{min}$. At lower temperature, the suspension

18 evaporation is slow and leads to agglomeration of the sprayed droplets. While evaporating, the

19 nanoparticles begin to form larger clusters, which are continuous in the spraying direction and

20 have lateral peripheral branches that grow perpendicular to the spraying direction as shown in

21 Fig. 8(a) and (b). These peripheral branches are caused by fingering instability [52]. The

22 instability occurs at the three phase contact line (gas, liquid, and particle) [57]. At higher

*Corresponding author. Tel. (+1) 515-294-6938

E-mail address: gykim@iastate.edu 
1 temperatures, the evaporation rate is higher, thus leading to the reduction of the droplet size

2 during travel [58]. A complete evaporation of relatively fine droplets may occur before they

3 even reach the surface [59], which results in a loss of particles and prevents deposition.

4 Moreover, the heated surface generates thermophoretic forces in an upward direction against the

5 droplet movement. These forces contribute to the drag forces that hinder the droplet freefall

6 and cause the droplets to deviate from their expected trajectory. For smaller droplets, the

7 deviation from the droplet trajectory is greater than that of the relatively larger ones [12]. If

8 complete evaporation occurs, the suspended particles do not have enough inertia to reach the

9 substrate, and therefore, they are carried away from the substrate. The inertia of the traveling

10 droplet needs to be above a critical value in order to overcome the thermophoretic forces and to

11 be successfully deposited on the surface [7]. As seen in Fig. 8(e) and (f), the substrate is nearly

12 free from any particle deposition at $400^{\circ} \mathrm{C}$.

13 Fig. 9 shows the effect of spraying air pressure on the deposited microstructure. The

14 samples were sprayed using a $0.1 \mathrm{wt} . \% \mathrm{SiC}(80 \mathrm{~nm})$-ethanol suspension at $350^{\circ} \mathrm{C}$, with a

15 suspension flow rate of $0.25 \mathrm{ml} / \mathrm{min}$, and at air pressure settings of $0.25,0.5$, and $1.0 \mathrm{kPa}$. At

16 the lowest air pressure $(0.25 \mathrm{kPa})$, no $\mathrm{SiC}$ particles were observed on the substrate. This may be

17 due to the lack of the force driving the nanoparticles to deposit on the substrate. As the droplet

18 travels towards the substrate, the droplet velocity decays due to the air drag and thermophoretic

19 forces [12]. At lower air pressure, the droplets take longer time to reach the substrate, which

20 leads to partial or complete evaporation during travel. This can result in loss of particles as

21 discussed earlier. The sample sprayed under an air pressure of $0.5 \mathrm{kPa}$ showed a wide range of

22 nanoparticle cluster size distribution as shown in Fig. 9 (a) and (b). As the air pressure

*Corresponding author. Tel. (+1) 515-294-6938

E-mail address: gykim@iastate.edu 
1 increased to $1.0 \mathrm{kPa}$, only relatively larger nanoparticle clusters were present on the deposition

2 surface, while smaller sized clusters were nearly absent. It is speculated that the violent air

3 streams from higher air pressure blew away the weakly attached deposited clusters [55]. The

4 nozzle distance from the deposition substrate had an effect similar to the effect of the air

5 pressure. There was no deposition of nanoparticles if the nozzle was either too close ( $D=15$

$6 \mathrm{~mm})$ or far $(\mathrm{D}=50 \mathrm{~mm})$ from the substrate. As a result, only a limited nozzle distance range

7 was available for each combination of spraying parameters.

8 The potential of fabricating AZ31-SiC laminate composites via ultrasonic spraying was

9 assessed by performing a three point bend test on synthesized composites. The eventual

10 deposited amount of $\mathrm{SiC}$ on the substrate was measured for the spraying condition used to

11 fabricate the composites $\left(\mathrm{T}=350^{\circ} \mathrm{C}, \mathrm{P}=0.5 \mathrm{kPa}\right.$, and $\left.\mathrm{Q}=0.25 \mathrm{ml} / \mathrm{min}\right)$. A direct measurement of

12 the deposited amount for each coupon, which requires 6-24 spray passes, was not possible since

13 the amount deposited fell below the resolution of the balance $(0.0001 \mathrm{~g})$. For this reason, the

14 suspension was sprayed for 200 passes on 10 coupons, and the average deposition per pass was

15 determined [60]. The measured deposition amount per pass for the set of conditions, $\mathrm{T}=350^{\circ} \mathrm{C}$,

$16 \mathrm{P}=0.5 \mathrm{kPa}$, and $\mathrm{Q}=0.25 \mathrm{ml} / \mathrm{min}$, was $0.0255 \mathrm{~g} / \mathrm{m}^{2}$.

17 The flexural stress and strain were calculated from the measured force and displacement

18 data using Eqns. (2) and (3) [61].

$$
\begin{gathered}
\sigma_{f l}=3 P L / 2 w h^{2} \\
\varepsilon_{f l}=6 d_{c} h / L^{2}
\end{gathered}
$$

$19 \sigma_{f l}$ and $\varepsilon_{f l}$ are the flexural stress and flexural strain, respectively. $\quad P$ is the load, $L$ is the support 20 span, $w$ and $h$ are the width and depth of the specimen, respectively, and $d_{c}$ is the deflection at

*Corresponding author. Tel. (+1) 515-294-6938

E-mail address: gykim@iastate.edu 
1 the middle of the span. Fig. 10 shows the flexural strength and strain of the consolidated

2 samples with different $\mathrm{SiC}(80 \mathrm{~nm})$ loadings $(0.15-0.6 \mathrm{wt} . \% \mathrm{SiC})$. The samples were sprayed at

$3350^{\circ} \mathrm{C}$, with a flow rate of $0.25 \mathrm{ml} / \mathrm{min}$ under a pressure of $0.5 \mathrm{kPa}$ and from a distance of 25

$4 \mathrm{~mm}$. The addition of $\mathrm{SiC}$ at the interface between the consolidated layers increased the yield

5 strength of the composite. The ultimate flexural strength, however, was only marginally

6 improved compared with the unreinforced sample. The SiC reinforcement strengthened the

7 composite until the yield, but did not change the hardening behavior since it was primarily

8 governed by the AZ31 substrate material properties. An excessive amount of $\mathrm{SiC}$ loading at the

9 interface resulted in degradation of mechanical properties as observed for $0.6 \mathrm{wt} . \% \mathrm{SiC}$ sample

10 in Fig. 10. Too thick of a layer of SiC nanoparticles prevented bonding of the AZ31 sheets.

11 To compare the effect of the deposition layer morphology on the mechanical properties of

12 the composite, a sample was synthesized with high flow rate $(1.0 \mathrm{ml} / \mathrm{min})$ while the other

13 parameters were kept the same. Such spraying conditions led to a nonuniform layer with large

14 porous nanoparticle clusters (see Fig. 7), and the synthesized composite showed poor mechanical

15 properties (see Fig. 10). As mentioned in earlier discussion, a high flow rate resulted in the

16 formation of large $\mathrm{SiC}$ clusters and a highly porous deposition microstructure. The large

17 clusters introduced uneven distribution of nanoparticles at the interface, and porous sites may act

18 as crack nucleation points, which contribute to early failure of the composite.

\section{Conclusions}

In this study, the dispersion and control of the deposited $\mathrm{SiC}$ nanoparticles were

21 investigated using the ultrasonic spraying process. The ultrasonic spray deposition is governed

*Corresponding author. Tel. (+1) 515-294-6938

E-mail address: gykim@iastate.edu 
1 by the suspension properties and the spraying parameters. The conclusions from this work can

2 be summarized as the following:

3 - The atomization droplet size was largely affected by the nozzle vibration frequency while the

$4 \quad$ suspension parameters only had a limited influence. According to Eqn (1), The change in

5 suspension concentration up to $16 \mathrm{wt}$ \% $\mathrm{SiC}$ only resulted in droplet size variation of

$6 \quad$ approximately $1 \mu \mathrm{m}$.

7 - The deposited nanoparticle cluster size and morphology were affected by two main factors:

8 the driving force that transports the atomized droplet from the nozzle to the substrate, and the

9 evaporation behavior of the droplet (the amount of liquid phase present on the substrate and

10 its evaporation rate). The amount of the liquid phase on the substrate and its evaporation

11 rate were determined by the flow rate and the deposition surface temperature. The driving

12 force is mainly determined by the air pressure and the nozzle to substrate distance.

13 - Having a large amount of liquid phase present on the substrate and low evaporation rate

14 increased the nanoparticle cluster size and resulted in nonuniform deposition microstructure.

15 Although a minimum inertia for the droplet is required for deposition of nanoparticles,

16 violent air streams may destruct the deposited structure.

17 - The use of ultrasonic spraying of nanoparticles showed a promising potential to fabricate 18 laminate composites. AZ31-0.3 wt.\% SiC composites with uniformly deposited 19 microstructure at the interface showed an improvement in the flexural yield strength by $49 \%$ 20 compared with the unreinforced AZ31, while composites with nonuniform structure or 21 thicker deposition layer exhibited deterioration in mechanical properties.

*Corresponding author. Tel. (+1) 515-294-6938

E-mail address: gykim@iastate.edu 


\section{Acknowledgment}

The authors greatly appreciate the financial support from Defense Advanced Research

Projects Agency (N66001-12-1-4257) and the United States National Science Foundation

4 (CMMI-1030120).

\section{References}

[1] L. Hao, D. Zhou, Q. Fu, Y. Hu, Multiferroic properties of multilayered BaTiO3CoFe2O4 composites via tape casting method, J Mater Sci, 48 (2013) 178-185.

[2] D. Bémer, R. Régnier, Y. Morele, F. Grippari, J.-C. Appert-collin, D. Thomas, Study of clogging and cleaning cycles of a pleated cartridge filter used in a thermal spraying process to filter ultrafine particles, Powder Technology, 234 (2013) 1-6.

[3] R. Hui, Z. Wang, O. Kesler, L. Rose, J. Jankovic, S. Yick, R. Maric, D. Ghosh, Thermal plasma spraying for SOFCs: Applications, potential advantages, and challenges, Journal of Power Sources, 170 (2007) 308-323.

[4] S.-R. Li, N. Yesibolati, Y. Qiao, S.-Y. Ge, X.-Y. Feng, J.-F. Zhu, C.-H. Chen, Electrostatic spray deposition of porous Fe2V4O13 films as electrodes for Li-ion batteries, Journal of Alloys and Compounds, 520 (2012) 77-82.

[5] I. Concina, N. Memarian, G.S. Selopal, M.M. Natile, G. Sberveglieri, A. Vomiero, Spray-assisted silar deposition of cadmium sulphide quantum dots on metal oxide films for excitonic solar cells, Journal of Power Sources, 240 (2013) 736-744.

[6] A. López, D. Acosta, A. I. Martínez, J. Santiago, Nanostructured low crystallized titanium dioxide thin films with good photocatalytic activity, Powder Technology, 202 (2010) 111-117.

[7] L. Liu, G.-Y. Kim, A. Chandra, Fabrication of solid oxide fuel cell anode electrode by spray pyrolysis, Journal of Power Sources, 195 (2010) 7046-7053.

[8] M. Dobre, L. Bolle, Practical design of ultrasonic spray devices: experimental testing of several atomizer geometries, Experimental Thermal and Fluid Science, 26 (2002) 205211.

[9] B. Barua, M.C. Saha, Ultrasound Assisted Hybrid Carbon Epoxy Composites Containing Carbon Nanotubes, Journal of Engineering Materials and Technology, 135 (2013) 011009-011009.

[10] C. Agashe, M.G. Takwale, B.R. Marathe, V.G. Bhide, Structural properties of SnO2: F films deposited by spray pyrolysis, Solar Energy Materials, 17 (1988) 99-117.

[11] P.S. Patil, Versatility of chemical spray pyrolysis technique, Materials Chemistry and Physics, 59 (1999) 185-198.

[12] U.P. Muecke, G.L. Messing, L.J. Gauckler, The Leidenfrost effect during spray pyrolysis of nickel oxide-gadolinia doped ceria composite thin films, Thin Solid Films, 517 (2009) 1515-1521.

*Corresponding author. Tel. (+1) 515-294-6938

E-mail address: gykim@iastate.edu 
[13] F. Ely, A. Matsumoto, B. Zoetebier, V.S. Peressinotto, M.K. Hirata, D.A. de Sousa, R. Maciel, Handheld and automated ultrasonic spray deposition of conductive PEDOT:PSS films and their application in AC EL devices, Organic Electronics, 15 (2014) 1062-1070.

[14] L. Liu, G.-Y. Kim, A.C. Hillier, A. Chandra, Microstructural and electrochemical impedance study of nickel-Ce0.9Gd0.1O1.95 anodes for solid oxide fuel cells fabricated by ultrasonic spray pyrolysis, Journal of Power Sources, 196 (2011) 3026-3032.

[15] M. Valdés, G. Santoro, M. Vázquez, Spray deposition of Cu2ZnSnS4 thin films, Journal of Alloys and Compounds, 585 (2014) 776-782.

[16] J. Yao, Y. He, D. Wang, J. Lin, High-temperature oxidation resistance of (A12O3$\mathrm{Y} 2 \mathrm{O} 3) /(\mathrm{Y} 2 \mathrm{O} 3$-stabilized $\mathrm{ZrO} 2)$ laminated coating on $8 \mathrm{Nb}-\mathrm{TiAl}$ alloy prepared by a novel spray pyrolysis, Corrosion Science, 80 (2014) 19-27.

[17] C.-H. Jung, J. Yun, K. Qadir, B. Naik, J.-Y. Yun, J.Y. Park, Catalytic activity of $\mathrm{Pt} / \mathrm{SiO} 2$ nanocatalysts synthesized via ultrasonic spray pyrolysis process under $\mathrm{CO}$ oxidation, Applied Catalysis B: Environmental, 154-155 (2014) 171-176.

[18] C.-P. Li, F. Lin, R.M. Richards, C. Engtrakul, R.C. Tenent, C.A. Wolden, The influence of sol-gel processing on the electrochromic properties of mesoporous WO3 films produced by ultrasonic spray deposition, Solar Energy Materials and Solar Cells, 121 (2014) 163-170.

[19] M. Dobre, L. Bolle, Visualisation and analysis of liquid film surface patterns formed on ultrasonic atomisers, ILASS-Europe'99, (1999).

[20] O. Wilhelm, S.E. Pratsinis, D. Perednis, L.J. Gauckler, Electrospray and pressurized spray deposition of yttria-stabilized zirconia films, Thin Solid Films, 479 (2005) 121-129.

[21] R.P. Reolon, C.M. Halmenschlager, R. Neagu, C. de Fraga Malfatti, C.P. Bergmann, Electrochemical performance of gadolinia-doped ceria (CGO) electrolyte thin films for ITSOFC deposited by spray pyrolysis, Journal of Power Sources, 261 (2014) 348-355.

[22] S.K. Das, S.U.S. Choi, H.E. Patel, Heat Transfer in Nanofluids-A Review, Heat Transfer Engineering, 27 (2006) 3-19.

[23] M. Jones, C. Li, A. Afjeh, G. Peterson, Experimental study of combustion characteristics of nanoscale metal and metal oxide additives in biofuel (ethanol), Nanoscale Research Letters, 6 (2011) 246.

[24] V. Sridhara, L. Satapathy, A12O3-based nanofluids: a review, Nanoscale Research Letters, 6 (2011) 1-16.

[25] A.D. Willey, J.M. Holt, B.A. Larsen, J.L. Blackburn, S. Liddiard, J. Abbott, M. Coffin, R.R. Vanfleet, R.C. Davis, Thin films of carbon nanotubes via ultrasonic spraying of suspensions in N-methyl-2-pyrrolidone and N-cyclohexyl-2-pyrrolidone, Journal of Vacuum Science and technology B, 32 (2014) 011218.

[26] B. Faure, J. Sæderup Lindeløv, M. Wahlberg, N. Adkins, P. Jackson, L. Bergström, Spray drying of TiO2 nanoparticles into redispersible granules, Powder Technology, 203 (2010) 384-388.

[27] H.-m. Bian, Y. Yang, Y. Wang, W. Tian, Preparation of nanostructured aluminatitania composite powders by spray drying, heat treatment and plasma treatment, Powder Technology, 219 (2012) 257-263.

*Corresponding author. Tel. (+1) 515-294-6938

E-mail address: gykim@iastate.edu 
[28] K. Kho, K. Hadinoto, Aqueous re-dispersibility characterization of spray-dried hollow spherical silica nano-aggregates, Powder Technology, 198 (2010) 354-363.

[29] P. Roy, G. Bertrand, C. Coddet, Spray drying and sintering of zirconia based hollow powders, Powder Technology, 157 (2005) 20-26.

[30] A.B.D. Nandiyanto, K. Okuyama, Progress in developing spray-drying methods for the production of controlled morphology particles: From the nanometer to submicrometer size ranges, Advanced Powder Technology, 22 (2011) 1-19.

[31] N. Ferrer-Anglada, V. Gomis, Z. El-Hachemi, U.D. Weglikovska, M. Kaempgen, S. Roth, Carbon nanotube based composites for electronic applications: CNT-conducting polymers, CNT-Cu, physica status solidi (a), 203 (2006) 1082-1087.

[32] H. Erismis, D. Nemec, M. Geiss, V. Skakalova, U. Ritter, I. Kolaric, S. Roth, Penetration based CNT/Sol-Gel composite films and their remarkable electrical properties, Microelectronic Engineering, 88 (2011) 2513-2515.

[33] S.I. Cha, B.K. Koo, S.H. Seo, D.Y. Lee, Pt-free transparent counter electrodes for dye-sensitized solar cells prepared from carbon nanotube micro-balls, Journal of Materials Chemistry, 20 (2010) 659-662.

[34] Y. Liu, S. Zha, M. Liu, Nanocomposite Electrodes Fabricated by a Particle-Solution Spraying Process for Low-Temperature SOFCs, Chemistry of Materials, 16 (2004) 35023506.

[35] L.B. Modesto-López, M. Miettinen, T. Torvela, A. Lähde, J. Jokiniemi, Direct deposition of graphene nanomaterial films on polymer-coated glass by ultrasonic spraying, Thin Solid Films, 578 (2015) 45-52.

[36] S. Lee, T. Oyama, J. Wadsworth, O.D. Sherby, Impact properties of a laminated composite based on ultrahigh carbon steel and brass, Materials Science and Engineering: A, 154 (1992) 133-137.

[37] M. Pozuelo, F. Carreño, O.A. Ruano, Delamination effect on the impact toughness of an ultrahigh carbon-mild steel laminate composite, Composites Science and Technology, 66 (2006) 2671-2676.

[38] P.B. Hoffman, J.C. Gibeling, Near-threshold fatigue crack growth in aluminum composite laminates, Scripta Metallurgica et Materialia, 32 (1995) 901-906.

[39] D.R. Lesuer, C.K. Syn, O.D. Sherby, J. Wadsworth, J.J. Lewandowski, W.H. Hunt, Mechanical behaviour of laminated metal composites, International Materials Reviews, 41 (1996) 169-197.

[40] M. Samadzadeh, M. Toroghinejad, The Influence of Carbon Nanotube and Roll Bonding Parameters on the Bond Strength of Al Sheets, J. of Materi Eng and Perform, 23 (2014) 1887-1895.

[41] M. Rezayat, A. Akbarzadeh, A. Owhadi, Fabrication of High-Strength $\mathrm{Al} / \mathrm{SiC} \mathrm{p}$ Nanocomposite Sheets by Accumulative Roll Bonding, Metall and Mat Trans A, 43 (2012) 2085-2093.

[42] C.W. Schmidt, C. Knieke, V. Maier, H.W. Höppel, W. Peukert, M. Göken, Accelerated grain refinement during accumulative roll bonding by nanoparticle reinforcement, Scripta Materialia, 64 (2011) 245-248.

*Corresponding author. Tel. (+1) 515-294-6938

E-mail address: gykim@iastate.edu 
[43] J.-K. Kim, J.Y. Jung, Y.T. Kang, The effect of nano-particles on the bubble absorption performance in a binary nanofluid, International Journal of Refrigeration, 29 (2006) 22-29.

[44] R.-H. Chen, T.X. Phuoc, D. Martello, Surface tension of evaporating nanofluid droplets, International Journal of Heat and Mass Transfer, 54 (2011) 2459-2466.

[45] Y. Wu, G.-Y. Kim, Carbon nanotube reinforced aluminum composite fabricated by semi-solid powder processing, Journal of Materials Processing Technology, 211 (2011) 1341-1347.

[46] V. Jokanović, D. Janaćković, D. Uskoković, Influence of aerosol formation mechanism by an ultrasonic field on particle size distribution of ceramic powders, Ultrasonics Sonochemistry, 6 (1999) 157-169.

[47] D.S. Zhu, S.Y. Wu, N. Wang, Surface Tension and Viscosity of Aluminum Oxide Nanofluids, AIP Conference Proceedings, 1207 (2010) 460-464.

[48] S. Tanvir, L. Qiao, Surface tension of Nanofluid-type fuels containing suspended nanomaterials, Nanoscale Research Letters, 7 (2012) 1-10.

[49] V. Saeid, P. Arup, J. Abhishek, R. Ganapathiraman, B.-T. Theodorian, The effect of nanoparticles on the liquid-gas surface tension of Bi 2 Te 3 nanofluids, Nanotechnology, 20 (2009) 185702.

[50] R. Kumar, D. Milanova, Effect of surface tension on nanotube nanofluids, Applied Physics Letters, 94 (2009) -.

[51] K.X. Steirer, M.O. Reese, B.L. Rupert, N. Kopidakis, D.C. Olson, R.T. Collins, D.S. Ginley, Ultrasonic spray deposition for production of organic solar cells, Solar Energy Materials and Solar Cells, 93 (2009) 447-453.

[52] M. Byun, N.B. Bowden, Z. Lin, Hierarchically Organized Structures Engineered from Controlled Evaporative Self-Assembly, Nano Letters, 10 (2010) 3111-3117.

[53] W. Han, Z. Lin, Learning from "Coffee Rings": Ordered Structures Enabled by Controlled Evaporative Self-Assembly, Angewandte Chemie International Edition, 51 (2012) 1534-1546.

[54] D.D. Robert, B. Olgica, F.D. Todd, H. Greb, R.N. Sidney, A.W. Thomas, Capillary flow as the cause of ring stains from dried liquid drops, Nature, 389 (1997) 827-829.

[55] O. Naoki, Y. Yeong, D. Isobel, Fabrication of Gas Electrodes by Wet Powder Spraying of Binder-Free Particle Suspensions Using a Pulse Injection Process, Journal of the American Ceramic Society, 90 (2007) 1365-1369.

[56] U.P. Muecke, N. Luechinger, L. Schlagenhauf, L.J. Gauckler, Initial stages of deposition and film formation during spray pyrolysis - Nickel oxide, cerium gadolinium oxide and mixtures thereof, Thin Solid Films, 517 (2009) 1522-1529.

[57] E. Pauliac-Vaujour, A. Stannard, C.P. Martin, M.O. Blunt, I. Notingher, P.J. Moriarty, I. Vancea, U. Thiele, Fingering Instabilities in Dewetting Nanofluids, Physical Review Letters, 100 (2008) 176102.

[58] R.P. Reolon, C.M. Halmenschlager, R. Neagu, C. de Fraga Malfatti, C.P. Bergmann, Electrochemical Performance Of Gadolinia-Doped Ceria (CGO) Electrolyte Thin Films For Itsofc Deposited By Spray Pyrolysis, Journal of Power Sources.

[59] D. Perednis, L. Gauckler, Thin Film Deposition Using Spray Pyrolysis, J Electroceram, 14 (2005) 103-111.

*Corresponding author. Tel. (+1) 515-294-6938

E-mail address: gykim@iastate.edu 
[60] D. Ragazzon, A. Nakaruk, C.C. Sorrell, Deposition rate of anatase films by ultrasonic spray pyrolysis, Advances in Applied Ceramics, 109 (2010) 196-199.

[61] Y. Wu, G.-Y. Kim, A.M. Russell, Effects of mechanical alloying on an A16061-CNT composite fabricated by semi-solid powder processing, Materials Science and Engineering: A, 538 (2012) 164-172. 


\section{Figure captions}

Fig. 1: Ultrasonic spray deposition system.

Fig. 2: (a) Schematic overview of the spraying process and (b) spraying path.

Fig. 3: Experimental setup used for consolidation of the metal laminate composites.

Fig. 4: The effect of SiC loading and particle size on the surface tension of ethanol-SiC suspension system.

Fig. 5: (a) Prediction of the atomization droplet size, and (b) prediction of the droplet size from the atomization using different atomization frequencies.

Fig. 6: An atomized droplet deposited by a single pass experiment.

Fig. 7: Effect of flow rate on the deposition structure $(\mathrm{a}, \mathrm{b}) 0.25 \mathrm{ml} / \mathrm{min}$, (c, d) 0.5 $\mathrm{ml} / \mathrm{min}$, and (e, f) $1.0 \mathrm{ml} / \mathrm{min}$

Fig. 8: Effect of temperature on the deposition structure, $(\mathrm{a}, \mathrm{b}) 200^{\circ} \mathrm{C}$, (c, d) $350^{\circ} \mathrm{C}$, and (e, f) $400^{\circ} \mathrm{C}$.

Fig. 9: Effect of air pressure on the deposition structure, (a, b) $0.5 \mathrm{kPa}$ and (c, d) $1.0 \mathrm{kPa}$.

Fig. 10: Flexural yield and ultimate strength of the consolidated AZ31-SiC composites. 


\section{Table captions}

Table 1: Summary of spraying parameters and their values.

Table 2: Chemical composition of the AZ31 sheets. 
Tables

Table 1: Summary of the spraying parameters and their values.

\begin{tabular}{ll}
\hline Parameters & Values \\
\hline Material and particle size & SiC nanoparticles $(<80 \mathrm{~nm})$ \\
Suspension medium and concentration & Ethanol $+0.1 \mathrm{wt} . \% \mathrm{SiC}$ \\
Substrate thickness & $80 \mu \mathrm{m}$ \\
Sonication time & 6 hours \\
Spraying type & Path spraying \\
Spraying speed & $10 \mathrm{~mm} / \mathrm{sec}$ \\
Spraying lines spacing & $2 \mathrm{~mm}$ \\
Temperature (T) & 200,350, and $400^{\circ} \mathrm{C}$ \\
Flow rate (Q) & $0.25,0.5$, and $1.0 \mathrm{ml} / \mathrm{min}$ \\
Air pressure (P) & $0.25,0.5$, and $1.0 \mathrm{kPa}$ \\
Distance (D) & 15,25, and $50 \mathrm{~mm}$ \\
\hline
\end{tabular}


Table 2: Chemical composition of the AZ31 sheets.

\begin{tabular}{cccccccccccc}
\hline \multicolumn{11}{c}{ Chemical Composition Limits of AZ31 in wt.\% } \\
\hline & $\mathrm{Al}$ & $\mathrm{Zn}$ & $\mathrm{Mn}$ & $\mathrm{Ca}$ & $\mathrm{Cu}$ & $\mathrm{Fe}$ & $\mathrm{Ni}$ & $\mathrm{Si}$ & $\begin{array}{c}\text { Others } \\
\text { Each }\end{array}$ & $\begin{array}{c}\text { Others } \\
\text { total }\end{array}$ & $\mathrm{Mg}$ \\
Min. & 2.5 & 0.7 & 0.2 & -- & -- & -- & -- & -- & -- & -- & Bal. \\
Max. & 3.5 & 1.3 & 1.0 & 0.04 & 0.05 & 0.005 & 0.005 & 0.05 & 0.1 & 0.3 & Bal. \\
\hline
\end{tabular}




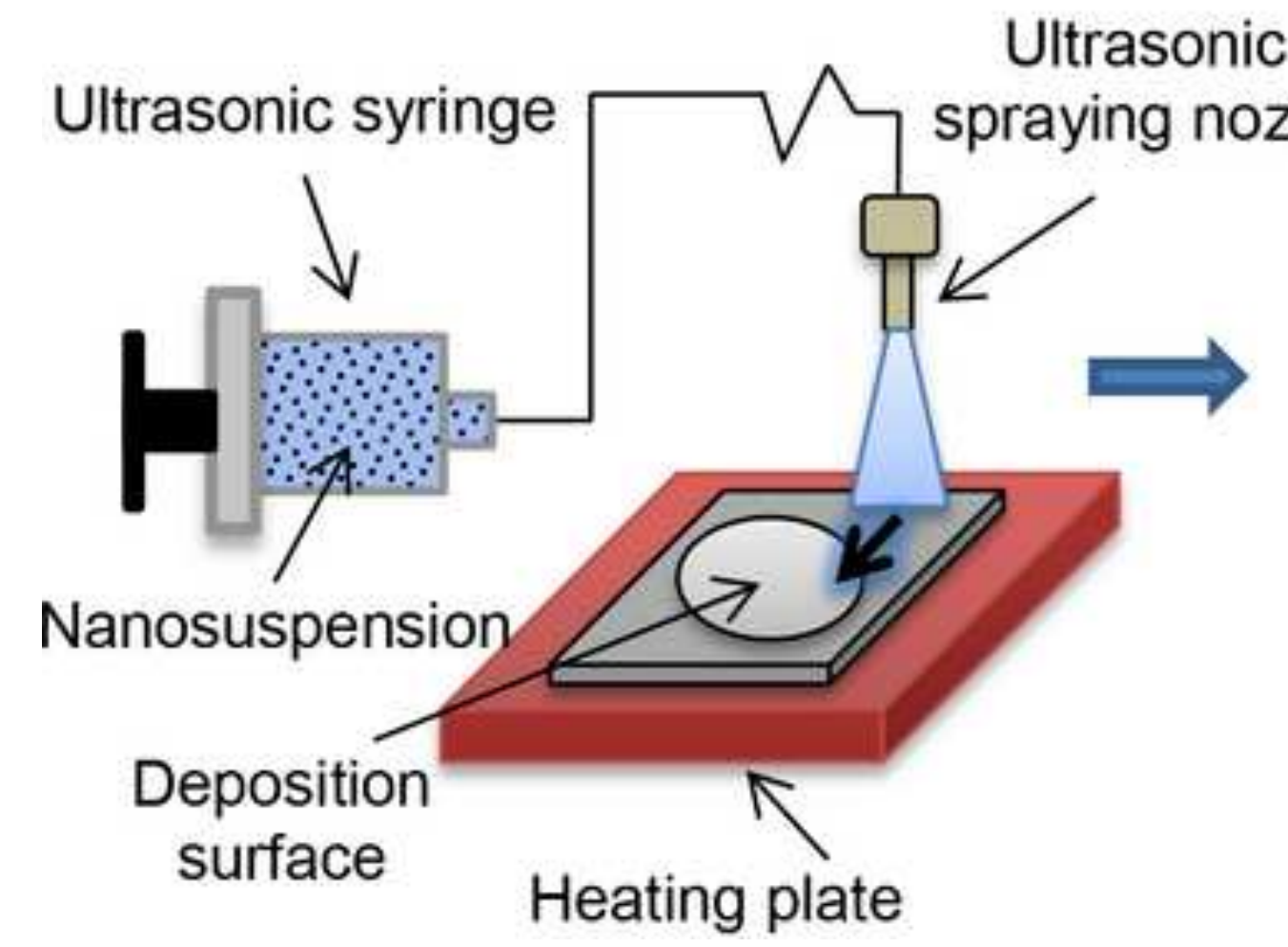

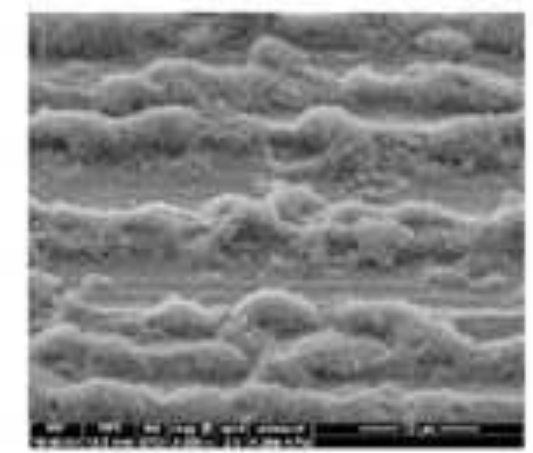

Uniform

$Q=0.5 \mathrm{ml} / \mathrm{min}$

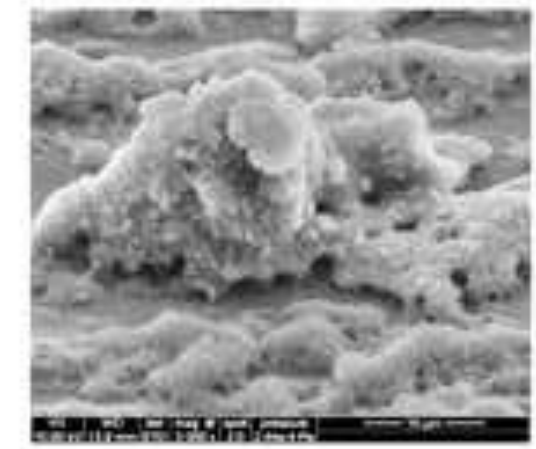

Nonuniform $\mathrm{Q}=1.0 \mathrm{ml} / \mathrm{min}$ 


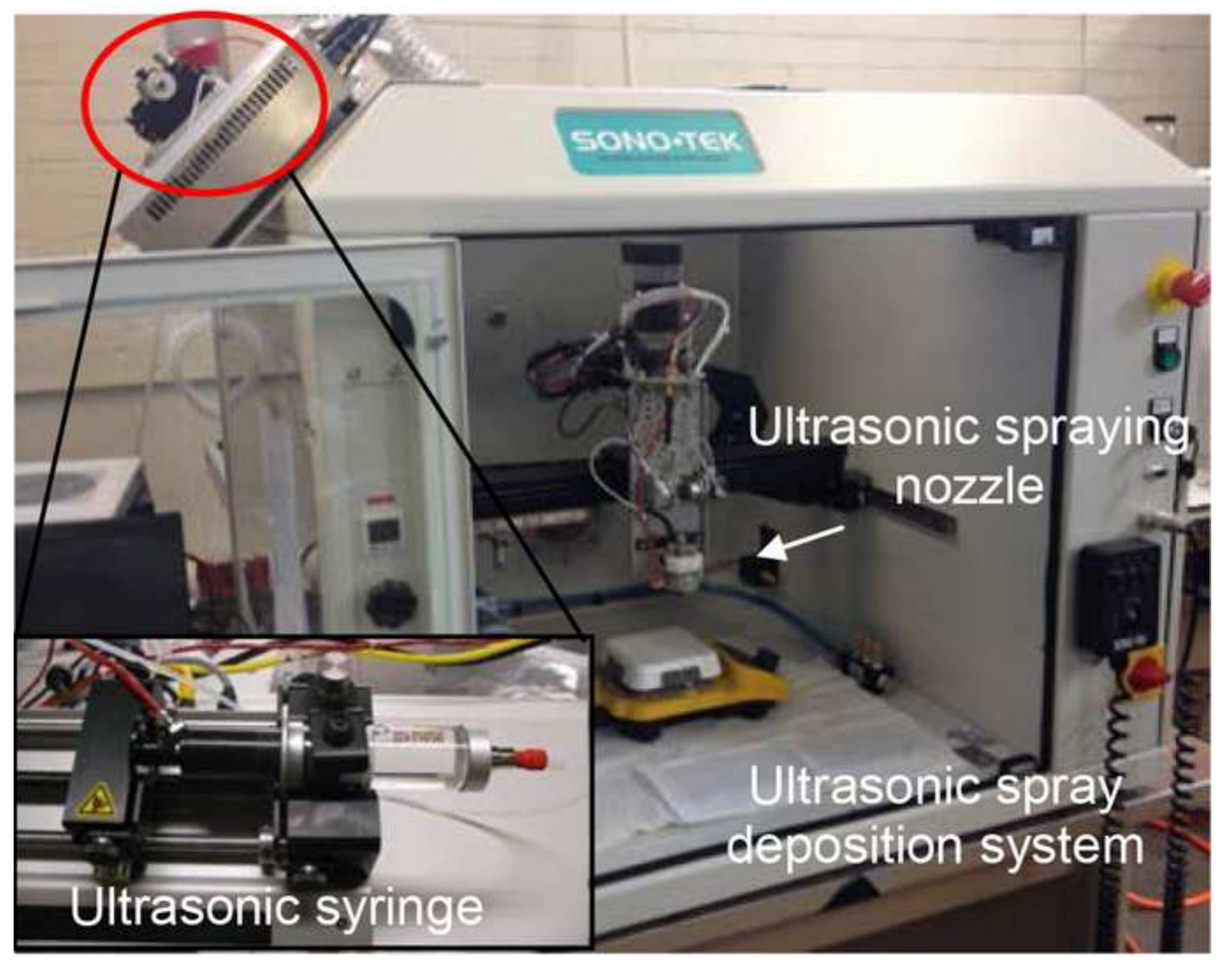

.

.

\section{Uitrasonic spraying;}

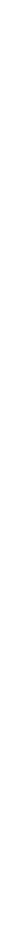

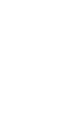
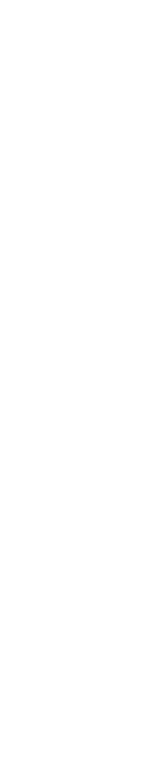
(a)

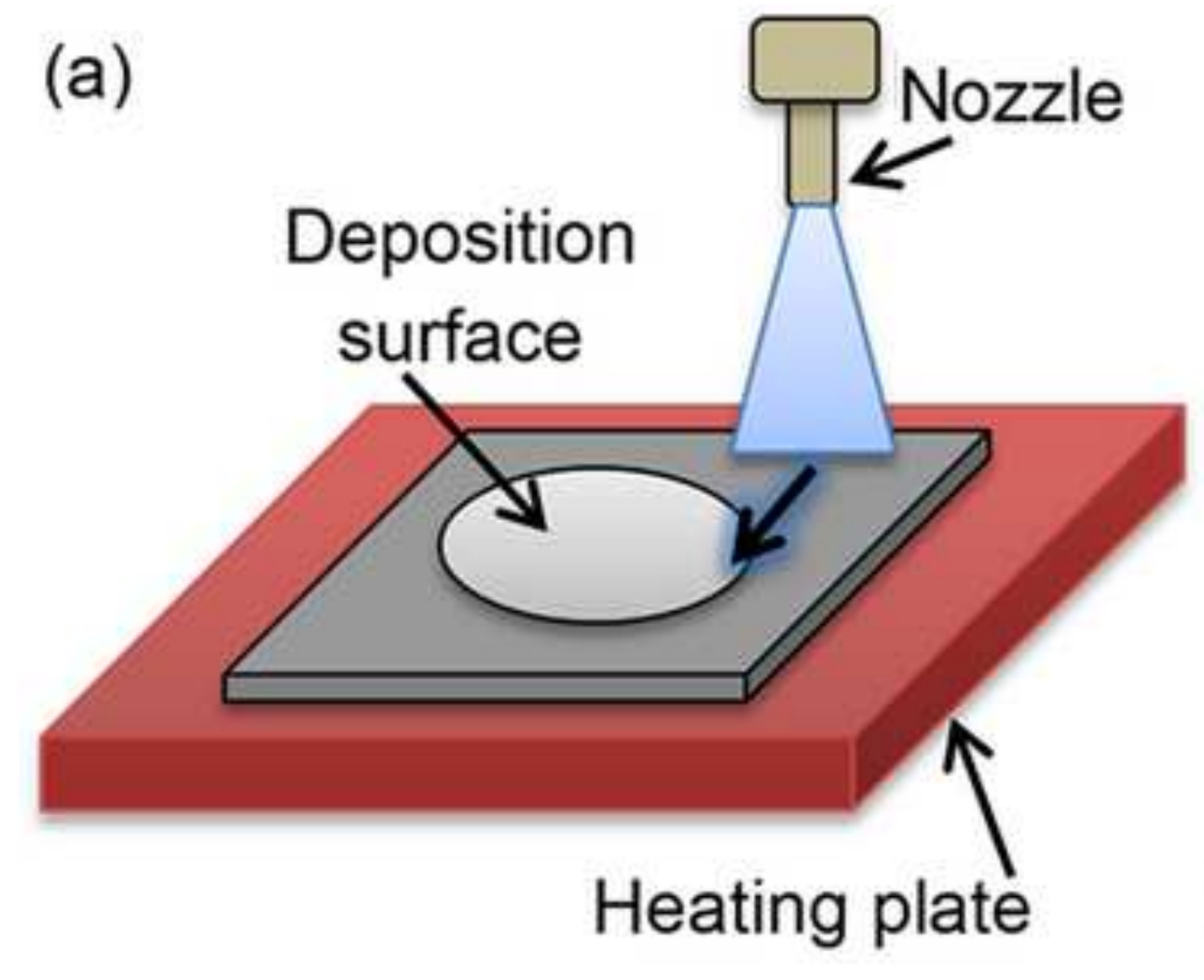

(b)

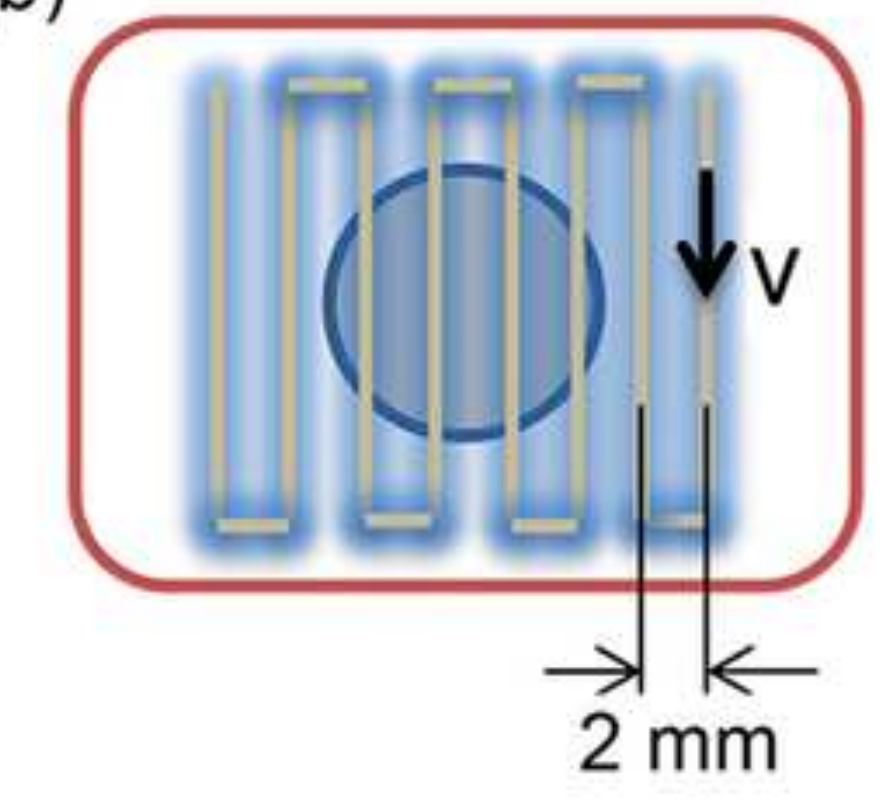

Spraying speed $(v)=10 \mathrm{~mm} / \mathrm{sec}$ 


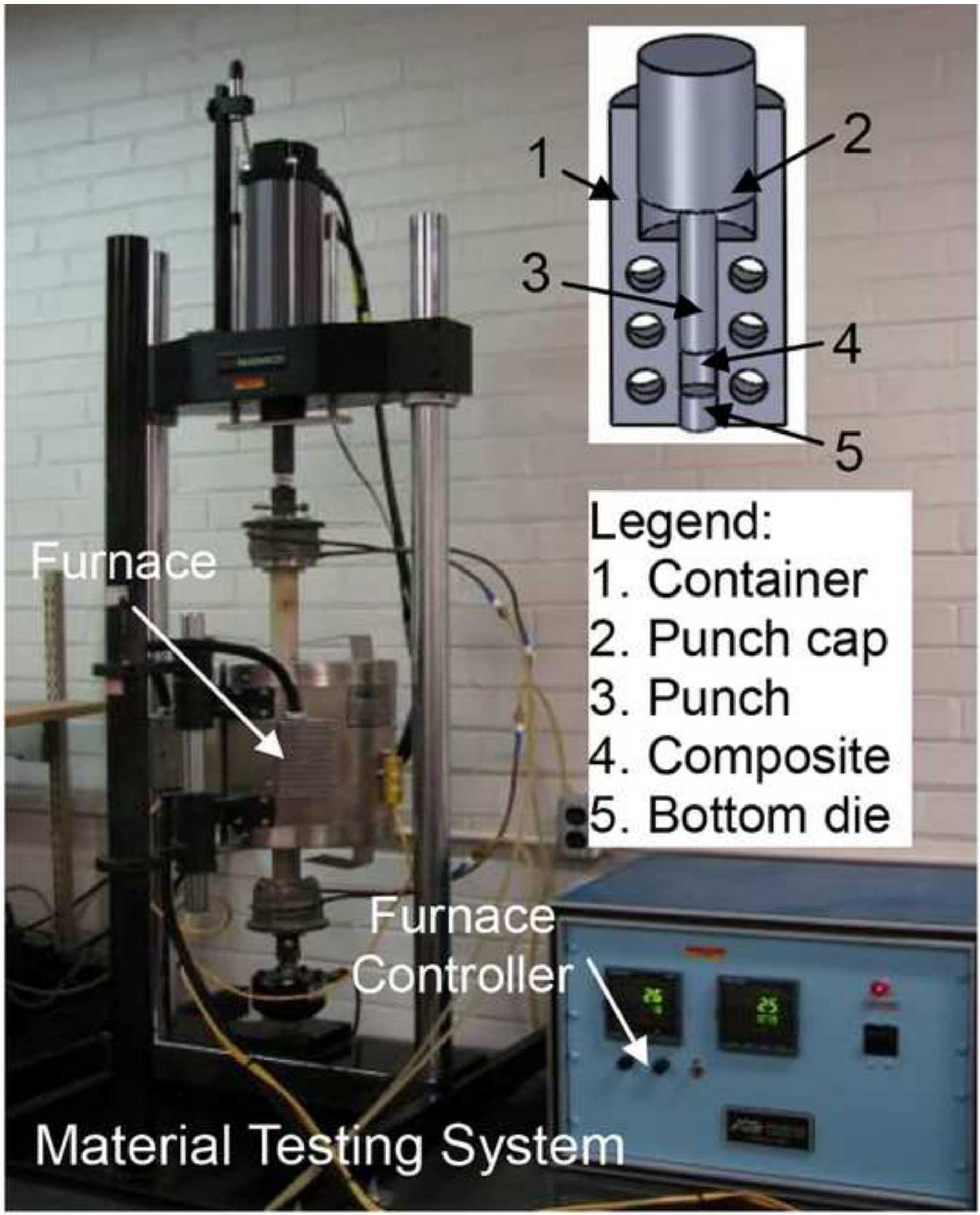


(a)

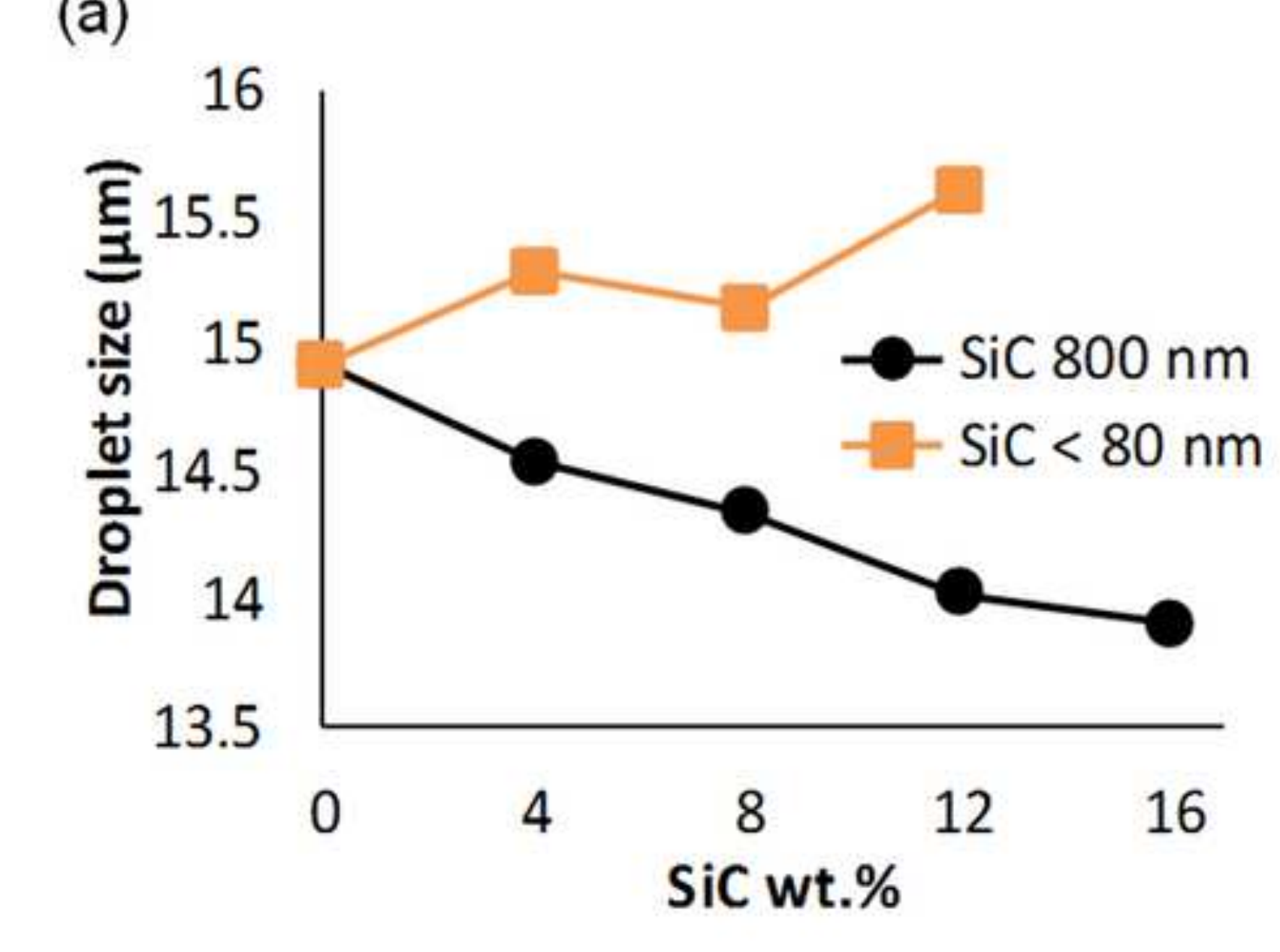

(b)

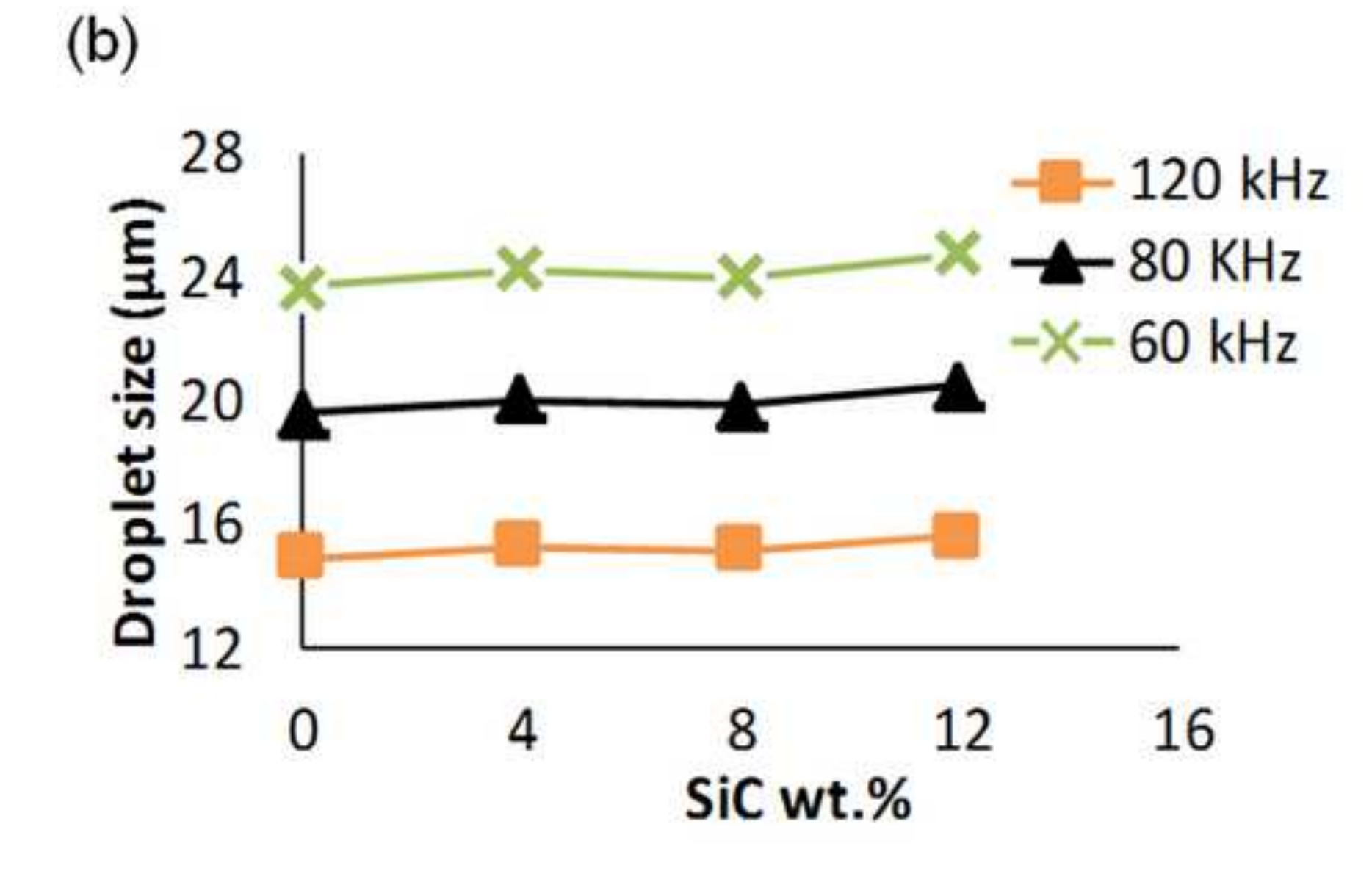

Fig. 5

of 5

.

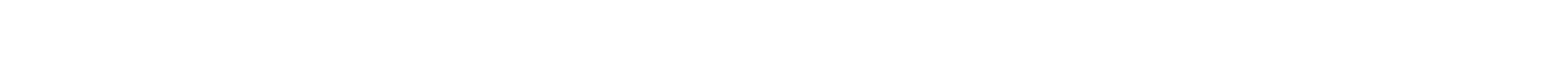

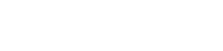
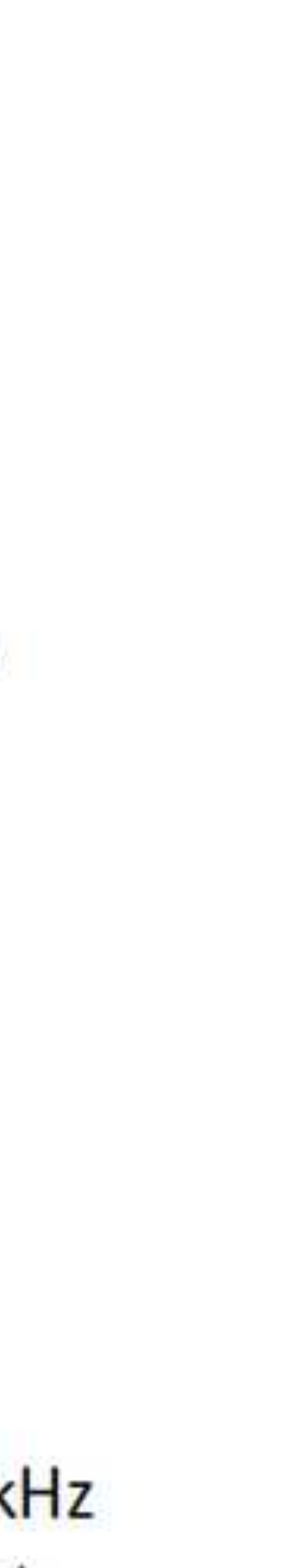


\section{(a)}

$30 \mu \mathrm{m}$
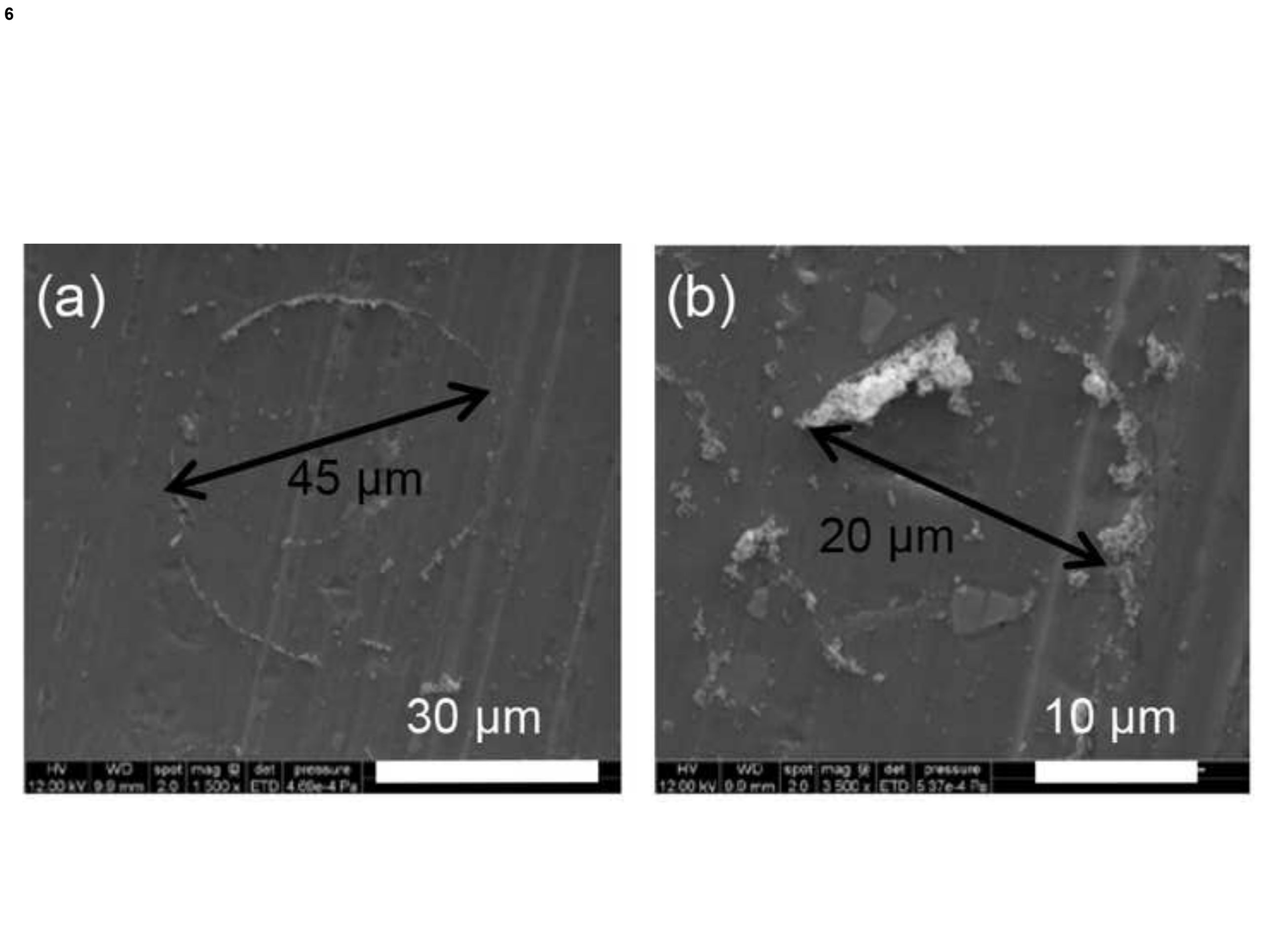

$10 \mu \mathrm{m}$
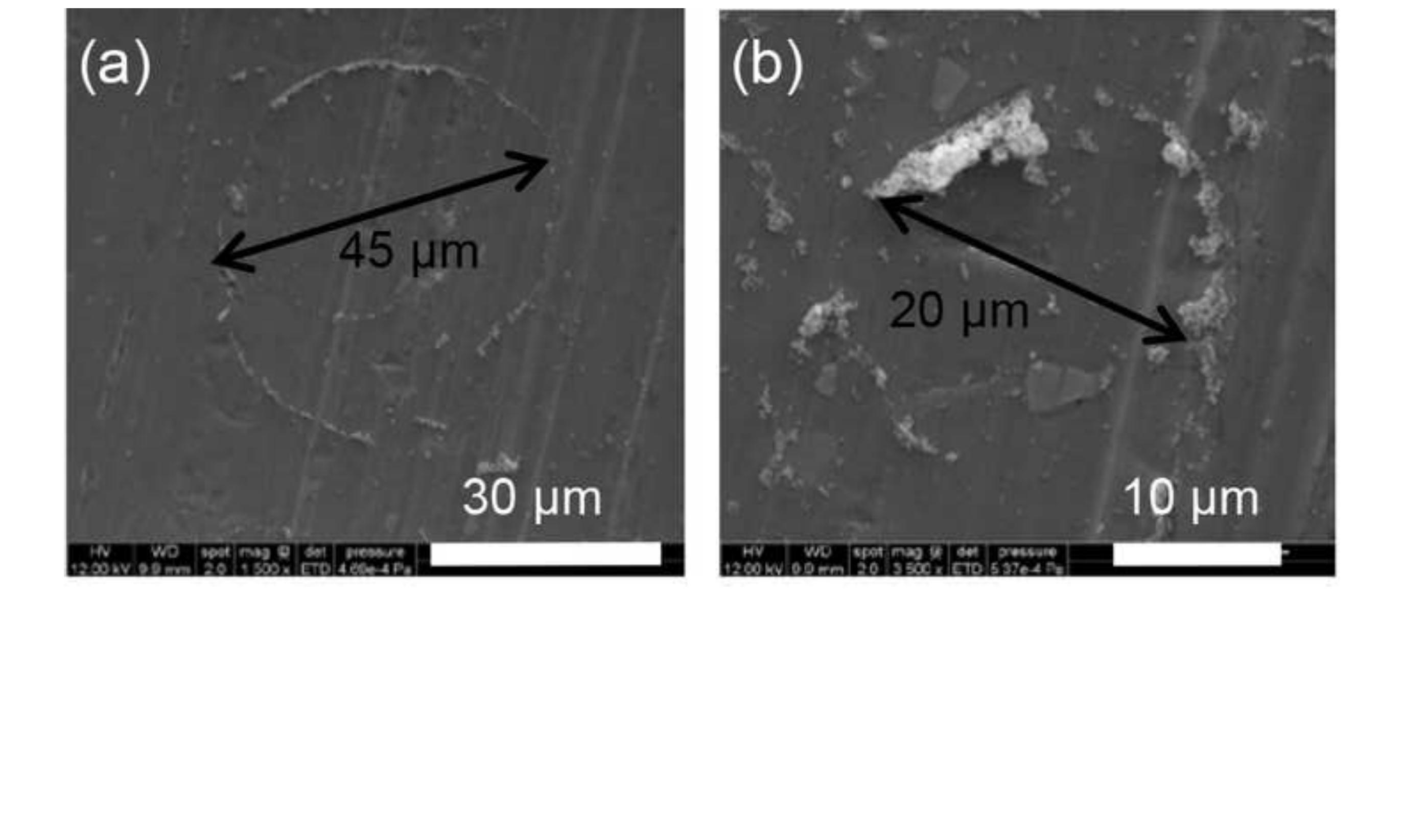
Fig. 7
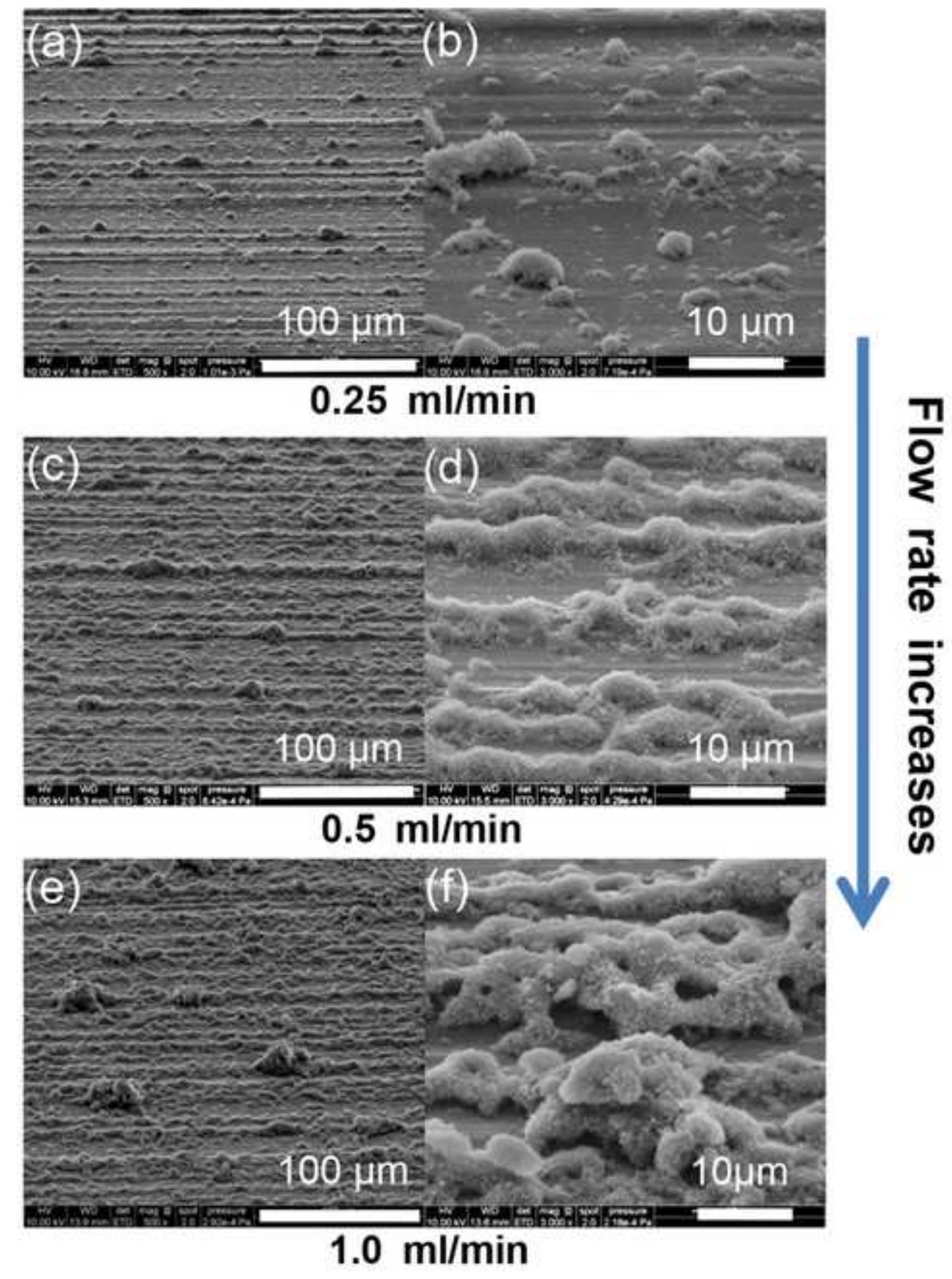

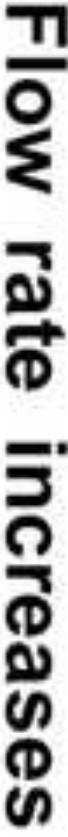

\section{$0.25 \mathrm{ml} / \mathrm{min}$}

.

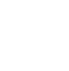

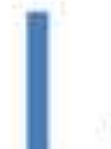
Spraying condition:
$T=350^{\circ} \mathrm{C} \quad \mathrm{D}=25 \mathrm{~mm} \quad \mathrm{P}=0.25 \mathrm{kPa}$

\section{Spraying condition:
$\mathrm{T}=350^{\circ} \mathrm{C} \quad \mathrm{D}=25 \mathrm{~mm} \quad \mathrm{P}=0.25 \mathrm{kPa}$}

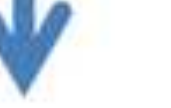


Fig. 8

\section{Spraying condition:}
$\mathrm{Q}=0.25 \mathrm{ml} / \mathrm{min}$
$\mathrm{D}=25 \mathrm{~mm}$
$\mathrm{P}=0.5 \mathrm{kPa}$
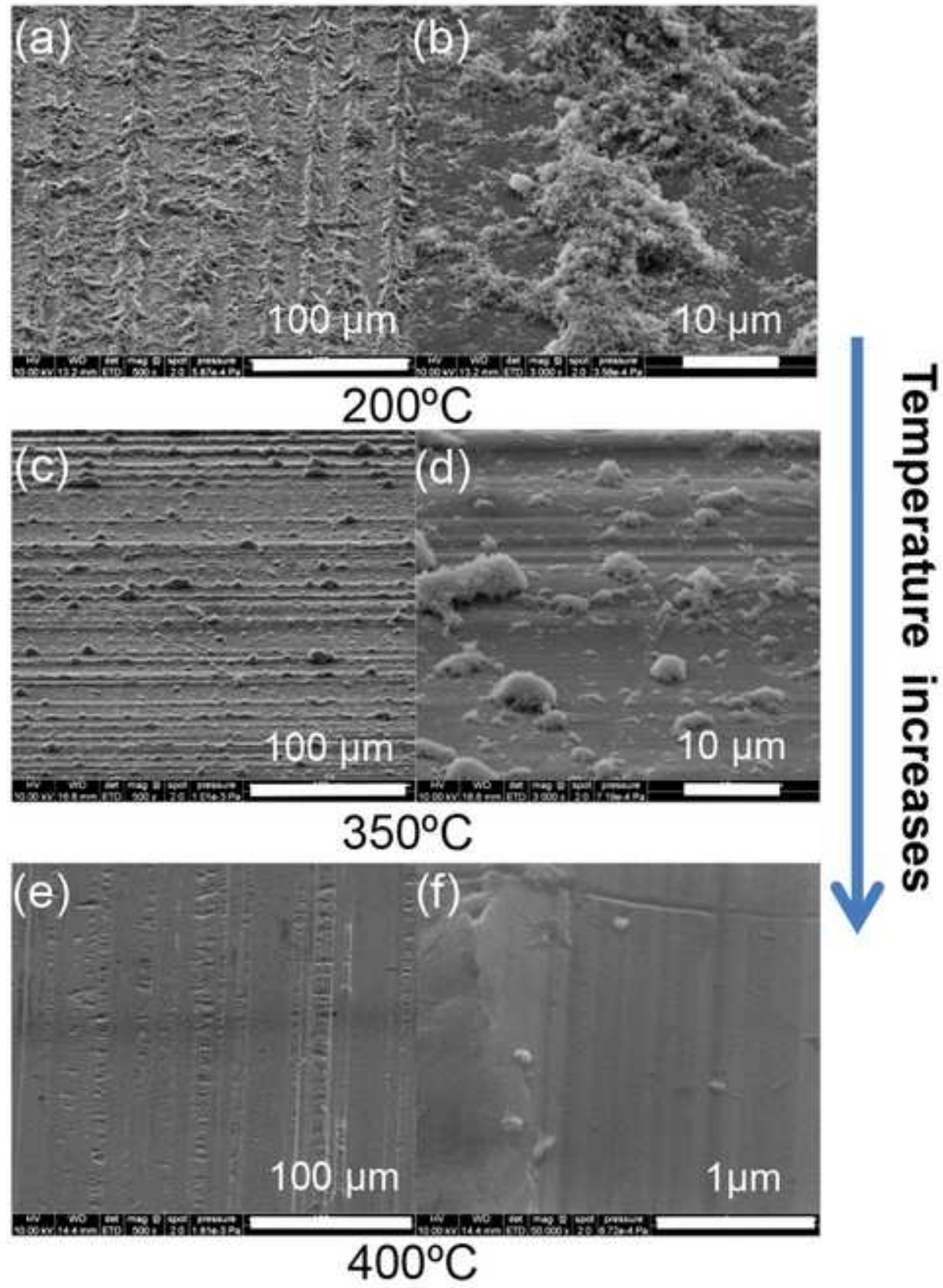


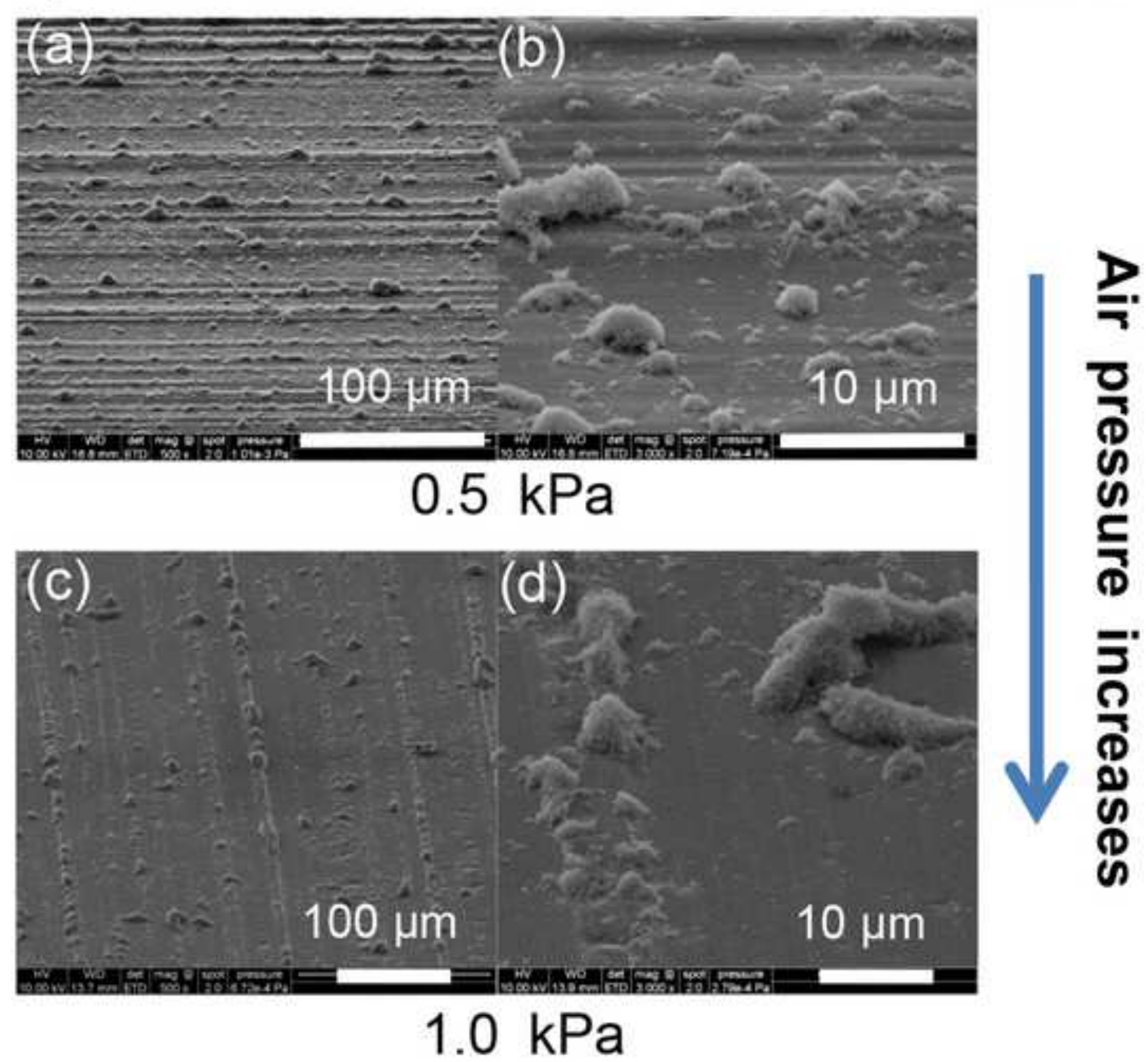

$0.5 \mathrm{kPa}$

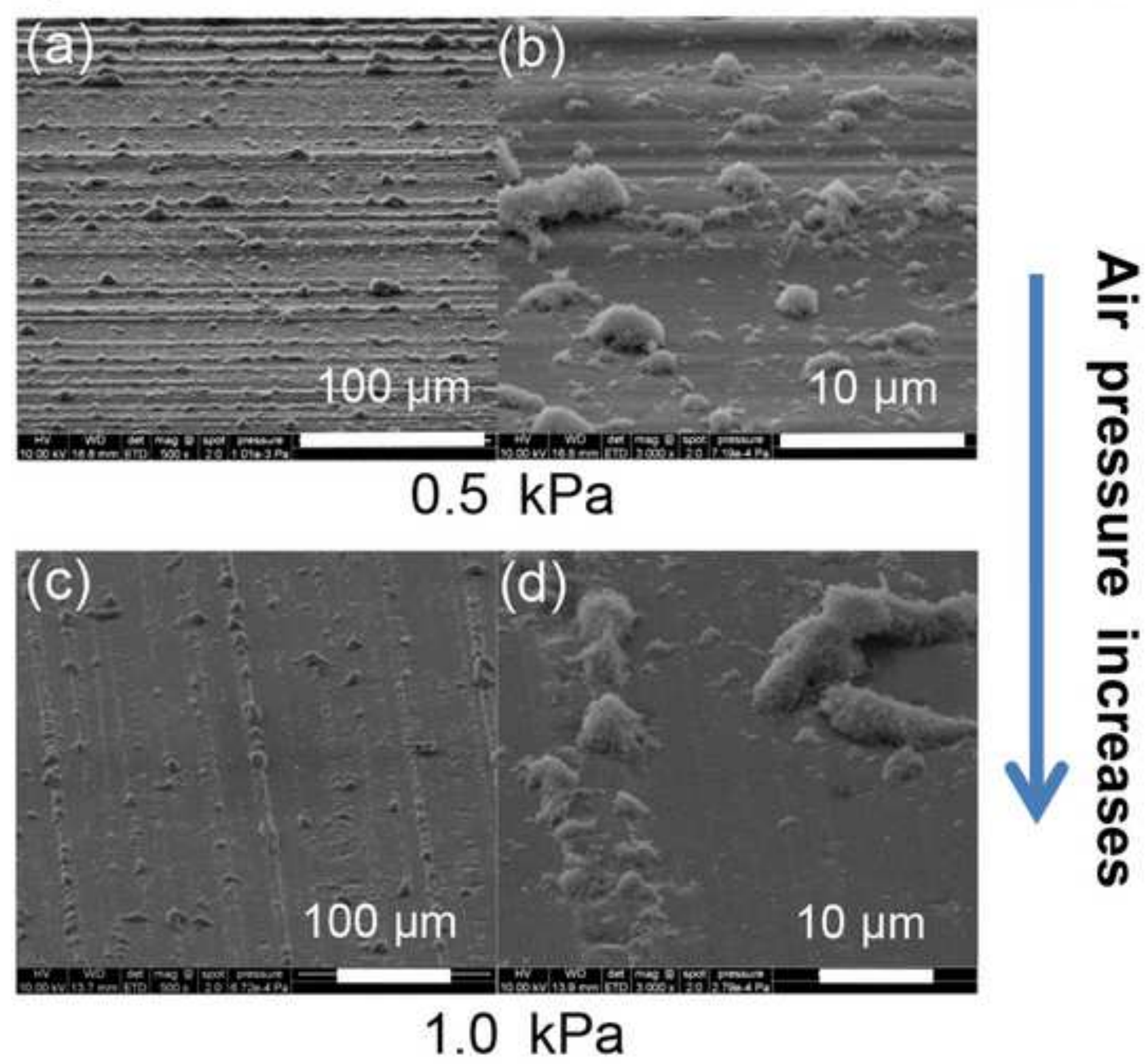

Fig. $S$

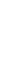

\section{Spraying condition: \\ $\mathrm{Q}=0.25 \mathrm{ml} / \mathrm{min} \quad \mathrm{D}=25 \mathrm{~mm} \quad \mathrm{~T}=350^{\circ} \mathrm{C}$}

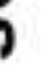


Flexural yield strength
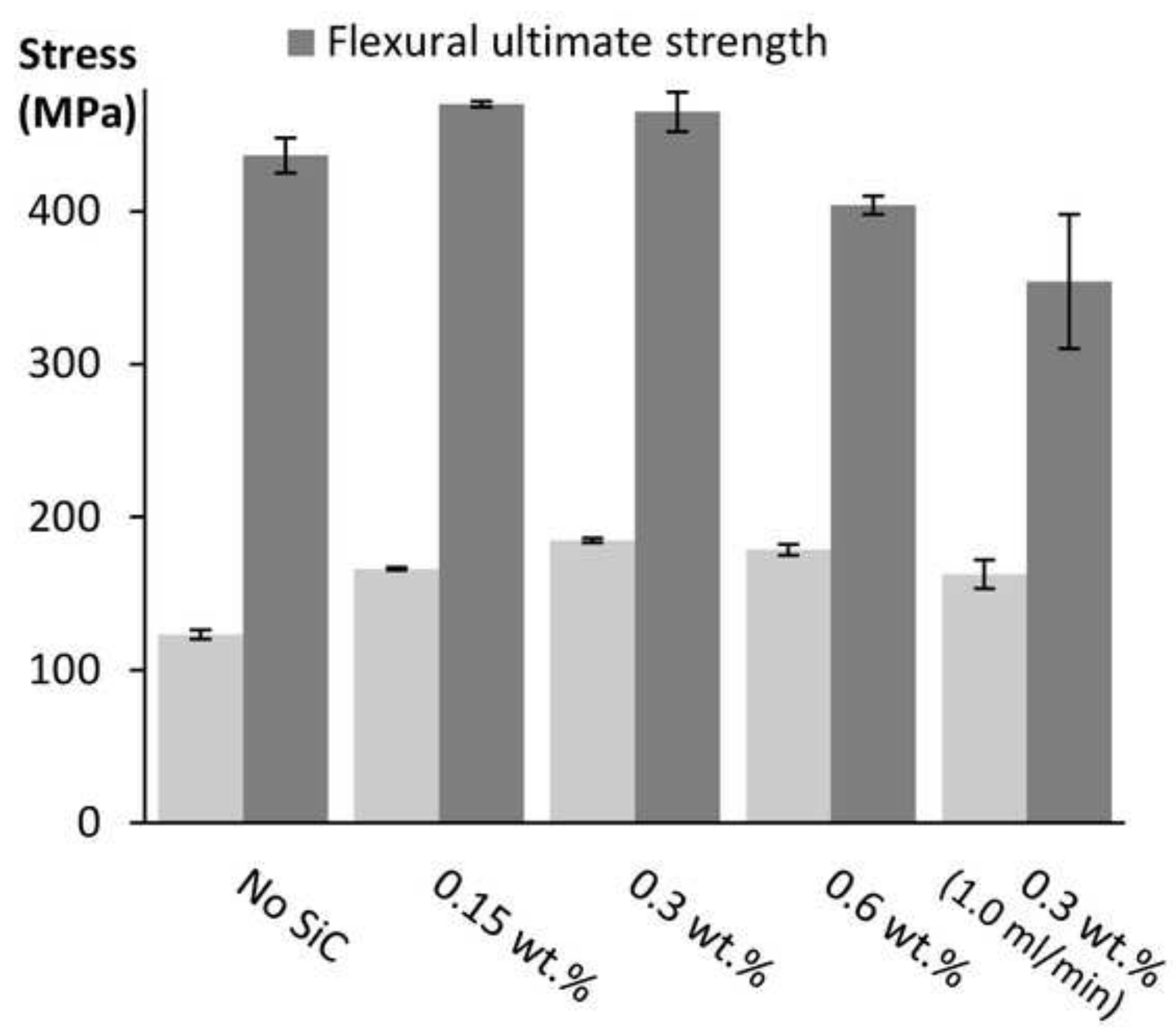